\title{
$\mathfrak{A} \mathfrak{H l e i t u n g}$
}

; $\mathrm{m}$

\section{rationellen \&otanifiren}

volt

3. Atucrowald.

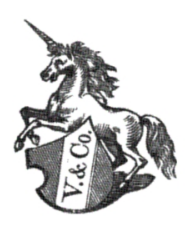

fripin,

Berlag woul beit \& Comp.

1860. 
